\title{
Searching for research results to inform the design of an initial professional teacher education programme for the foundation phase: A systematic review
}

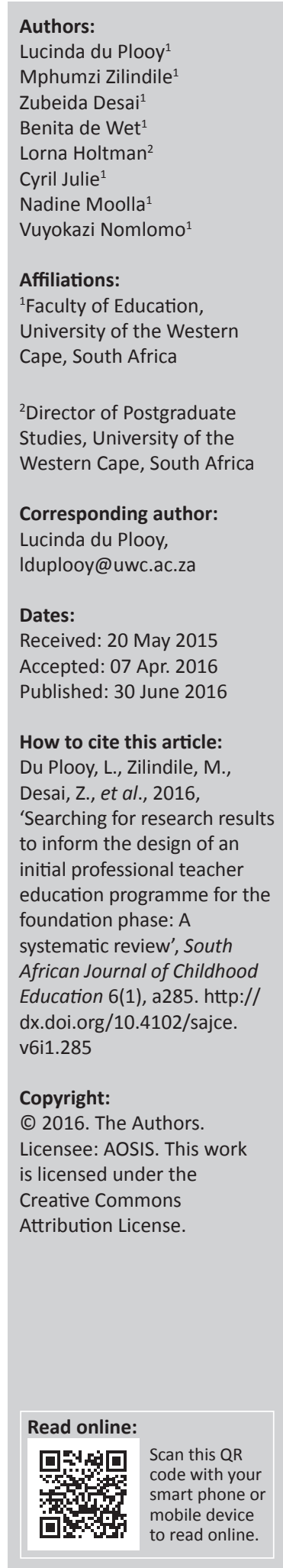

This article reports on a systematic review conducted to inform the development of a professional teacher education programme for the foundation phase of schooling. The research question was: What do quality research studies identify as the components and/or characteristics of quality teacher education for the foundation phase programmes that allow new teachers to begin to teach for epistemological access. A search for systematic reviews on educational programmes related to foundation phase for initial teacher education was conducted for the period between 1980 and 2011. The researchers added Stage 0 as a fifth step to the traditional four-step systematic review process. Stage 0 or quasi-tertiary review allowed us to present substantive findings of the identified systematic reviews and to explore their methodological quality. From the initial 2876 hits (mostly health and medical studies), only 19 studies were related to the educational field. Only three of the 19 studies were finally accepted as eligible at Stage 0 . None of the reviews directly addressed programme design but contained elements that were considered as useful when designing programmes. The present study makes it clear that there is a dearth of research on entire programmes related to initial teacher education for foundation phase teachers.

\section{Introduction}

Much concern is expressed about the return on investment of research in education. Pring (2000) refers to investments to the tune of approximately $\$ 1$ billion in the United States and approximately $£ 100$ million in the United Kingdom, but many believe that this money is not well spent. The criticisms are primarily based on the following:

- Research not providing answers to questions of importance to government.

- Research not helping professional practice.

- Research being fragmented - bits and pieces on the same issue, different philosophical underpinnings.

- Research being highly political, driven at overt and covert levels, and 'political' with a small ' $\mathrm{p}$ ' and a big 'P' (Pring 2000:1).

Burkhardt and Schoenfeld (2003) share Pring's concern about the usefulness of educational research as it pertains to providing practitioners and policy makers with better-informed and less speculative information for decision-making for practice. They refer to the U.S. Department of Education's Strategic Plan for 2002 and 2007 (2002), which insists on educational policies and practices being more evidence driven. Focussing on science and mathematics education, Yore and Lerman (2008) refer to the state of maturity reached by these disciplines, which does allow for the plethora of research results to be subjected to systematic reviews as is, for example, done in nursing education (Bowman 2007) to inform policy and practice. It is our contention that the design of a degree programme for the initial professional education of teachers for the foundation phase (Grades R-3) should also be evidenced based. A systematic review is a mechanism to gather best evidence to inform such programme design.

\section{Systematic reviews}

A systematic review is an investigation of the findings related to studies in an area of interest (Bowman 2007; Pawson 2004). It seeks to identify, evaluate, and summarise the findings of all relevant individual studies (Centre for Reviews and Dissemination (CRD) 2009). A systematic review is driven by a review question. It analyses the results forthcoming from research by assessing whether the results were obtained by credible and appropriate methods. In addition to 
providing policy makers, decision makers and practitioners with the best available evidence emanating from research, systematic reviews are also conducted to, amongst other things, create new knowledge and theory building related to the topic under scrutiny, produce 'midrange' theory dealing with inconsistencies and variability in studies and facilitate the accessibility of best evidence to researchers.

A systematic review is not a conventional background literature review which normally seeks for results pertaining to forthcoming research, highlights the theoretical and/or conceptual frameworks and suggests how the study that is being embarked upon can benefit or not benefit from the insights emanating from the extant literature. Nor is it a re-analysis of the original data used in a particular study. Finally, a systematic review is not the organisation of a set of studies, conducted in a domain over a period of time either appearing in one particular journal (e.g. Lerman, Xu \& Tsatsaroni 2002) or for a specific location (Rolnick, Adler \& Setati 2009), according to a pre-specified template. Such studies are often presented as systematic reviews but they do not assess the results of the studies, evaluate methodological appropriateness or consider the appropriateness of the underlying theoretical stance of the studies included in their corpus. Jablonka (2009), for example, brings to the fore that although the exemplar study used by Lerman et al. (2002) claimed to be ethnomethodological in orientation and was accepted as such by the review authors, there is little evidence in the exemplar study that the tenets of ethnomethodology were adhered to. The special issue of the African Journal of Mathematics, Science and Technology, sponsored by the Marang Centre of the University of Witwatersrand, similarly lays claim to having conducted a systematic review, but there is very little evidence of a systematic review question, assessment of results, methodological evaluation or consideration of the appropriateness of underlying theoretical frameworks. These kinds of reviews serve to systematically organise studies to provide some report card on who does what and the current status of things. Despite their not being systematic reviews, they do provide useful information for researchers.

As is obvious from the above, a systematic review is therefore conducted in some procedural manner. The procedural steps and its application for this study are discussed in the next section.

\section{Methodology}

As mentioned above, a systematic review is driven by a review question or interrogative statement. More broadly, a systematic review commences with a systematic review protocol which, in addition to declaring the review question, also contains modalities such as the time period of the studies to be selected, inclusion and exclusion criteria to be employed, the methods to be followed, the kinds (qualitative or quantitative or both) of studies to be included and the review participants. For this study, an initial review protocol was developed and after consideration by the systematic review group, it was distributed to project members of the Cape Foundation Phase Research Programme at Rhodes University, Walter Sisulu University, the Nelson Mandela Metropolitan University and a member of the teacher education section of the Department of Higher Education and Training (South Africa) for comments on clarity and suggestions for improvement. Recommendations were received from only one of these requestees and these were included in the systematic review protocol which is presented in Appendix 1. The review question for this systematic review is given as 'What do quality research studies identify as the components / characteristics of quality teacher education for foundation phase programmes that allow new teachers to begin to teach for epistemological access?'

Normally, the systematic review process is based on a fourstage process with the first stage being the identification of potential studies. This is followed by the second stage which entails the application of the inclusion and exclusion criteria pertinent to the review. The third stage is the characterisation and the final stage is the in-depth review process (Cordingley et al. 2003).

For the first stage, it is recommended that:

it is necessary to check whether there are already existing or ongoing reviews, and whether a new review is justified. It starts with the search for conducting systematic reviews of the topic under scrutiny. (CRD 2009:3)

For this study, an initial search was conducted to ascertain whether or not any systematic reviews on educational programmes relating to foundation phase for initial teacher education were conducted covering research studies published between 1980 and 2011. For our purposes, we label this search for completed systematic reviews on a topic as Stage 0. Our Stage 0 is a quasi 'tertiary' review which is defined as:

a systematic review where the included studies are themselves systematic reviews. The tertiary review fulfils two purposes: it presents the substantive findings of the identified systematic reviews and it explores their methodological quality. (Torgerson 2007:287)

To start the process, a research team consisting of seven members attended a presentation by the primary reviewer on what a systematic review is and how systematic reviews are done. Following this, an advance search on Google and Google Scholar, and other online library databases were done to ascertain whether or not there were any systematic reviews done in the period between 1980 and 2011 relating to our research question. This search (Stage 0) was conducted in April 2011 using the following keywords (search phrases):

- Systematic review + teacher education programmes + 1980-2011.

- Systematic review + education programmes + pre-service and in-service teaching. 
- Systematic review + teacher education programmes + primary education.

- Systematic review + teacher education programmes + South African primary schools.

- Systematic review + teacher education programmes + elementary schools.

- Systematic reviews + teacher training programmes + primary schools.

- Systematic review + teacher training programmes + foundation phase schooling.

It should be noted that other concepts were also used interchangeably, such as 'INSET', 'teacher training', 'education' and 'primary school'. Both the American and British spellings of the word 'programmes' were used in the search.

From this initial search for systematic reviews, we got 2895 hits. What we discovered was that most of these systematic reviews were related to the fields of medicine and health. Only 19 hits were related to the field of education. Of the 19 publications, 13 were international publications, 2 crossnational and only four studies were related to the South African context.

For systematic reviews, the assessment and evaluation of identified studies is driven by an appraisal template. An appraisal template (Appendix 2) was designed by the University of the Western Cape (UWC) project members. It was inspired by a checklist suggested by the CRD (2009:4) and was used to appraise the 19 publications in terms of whether or not they were systematic reviews, whether they spoke directly to the research question or whether they should be banked for later use in this research process. The 19 publications (Appendix 3) were divided amongst the UWC project members (the reviewers). Two reviewers reviewed the same publication in order to eliminate personal biases. From the review process, seven publications were rejected since these were either opinion pieces or reports based on literature reviews and not systematic reviews. A further nine also fell into this category (they were not systematic reviews) but these were banked for possible usefulness to the foundation phase research project. A screening of the publications of the remaining three publications indicated that they were not as specific with respect to Grades R-3 as specified in the review question. However, two of them dealt with more generic issues related to teacher education and one focussed on early childhood development programmes.

The three publications that were deemed useful systematic reviews and that were accepted for conducting the Stage 0 appraisal were Evans, Harden and Thomas (2004), Nordenbo et al. (2008) and Chambers et al. (2010). Figure 1 diagrammatically presents the process followed to arrive at the three systematic studies.

Before commenting on whether or not these publications could be used to inform the design and development of an initial professional teacher education programme for the foundation phase, an elucidation of the review question of

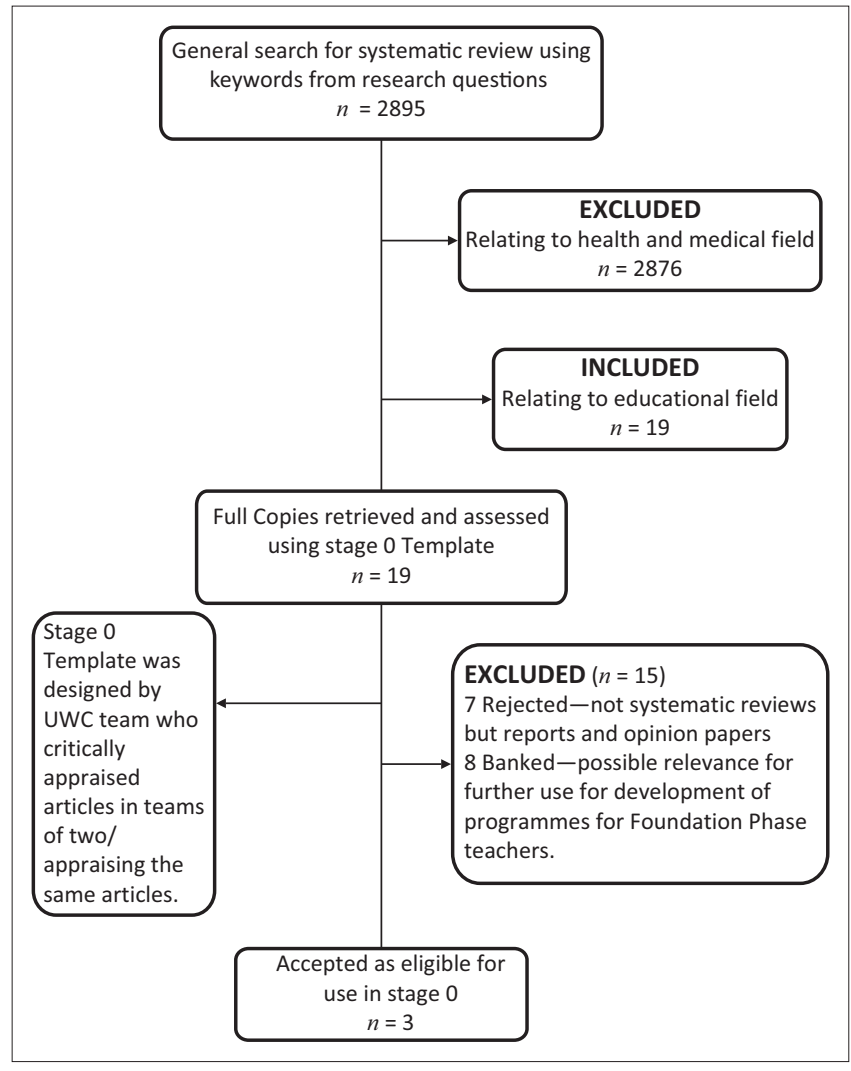

Source: Adopted from Centre for Reviews and Dissemination (CRD), 2009, Systematic Reviews: CRD's guidance for undertaking reviews in health care, CRD, University of York, York FIGURE 1: Flow chart of selection process for Stage 0 .

each publication is given. All three systematic reviews had clearly defined review questions.

Evans et al. (2004) had as review question 'What are effective strategies to support pupils with emotional and behavioural difficulties (EBD) in mainstream primary schools?'

The focus is on:

What is known about the effectiveness of different strategies currently advocated for supporting children with emotional and behavioural difficulties. (Evans et al. 2004:2)

The review question for the systematic review conducted by Nordenbo et al. (2008) was: 'Which dimensions of teachers' manifest competencies could contribute to pupil achievement?' The focus is on 'manifest competence' (competencies which are manifested during the execution of professional activity) and not 'formal competence' (competencies acquired during formal education and training). Chambers et al. (2010) reviewed early childhood education programmes, and their focus was on the effectiveness of these programmes.

An initial assessment of the three systematic reviews was done to ascertain whether they could inform an initial professional teacher education programme for the foundation phase. Each publication was reviewed by two members of the team, both reviewing and reporting on how these publications were of use to our particular project (an example of a review report by a team member is given in 
Appendix 4). Each of the systematic reviews was appraised using the criteria for critically appraising systematic reviews. This appraisal process formed part of the initial Stage 0 template (Appendix 2). Two of these reviews met all eight criteria. Nordenbo et al. (2008) only met seven of the eight required criteria. In the next section, a summary and the results of the three selected systematic reviews for Stage 0 are presented.

\section{Findings}

Table 1 summarises the three systematic review studies that were found relevant for the pursuit of the review question.

\section{The quality of the selected systematic reviews}

The assessment of the quality of the studies included is a crucial part of the systematic review process. For the CRD (2009), the quality assessment of studies is the key:

to assess the risk of bias in included studies caused by inadequacies in the study design, conduct or analyses that may have led to the treatment effect being over or underestimated. (p. 44)
An assessment tool adapted from the tool used by the CRD (2009) and Torgerson (2007) was used to assess the three systematic reviews. Table 2 presents the outcomes of the application of the tool. It is clear from Table 2 that the three systematic review studies comply with the quality criteria for systematic reviews.

\section{Findings of relevance for programme design}

An analysis of the three included systematic reviews indicates that none of these reviews directly addressed the programme design. Each of them, however, contains elements which could be considered when designing a programme. Evans et al. (2004) focus on classroom-based research. Their empirical field is learners between the ages of 6 and 9, which fall within the scope of this project. They found that effective strategies for supporting young children (aged between 6 and 9 years) with EBD include a system of rewards such as:

Teachers [using] visual aids such as graphs or symbols (e.g., smiley faces, red ribbons) to show children how well they were progressing towards receiving a reward. (Evans et al. 2004:6)

TABLE 1: Summary of three systematic reviews.

\begin{tabular}{|c|c|c|c|}
\hline Author(s), date & Evans, Harden \& Thomas (2004) & Nordenbo et al. (2008) & Chambers et al. (2010) \\
\hline Title of report & $\begin{array}{l}\text { What are effective strategies to support pupils } \\
\text { with emotional and behavioural difficulties (EBD) } \\
\text { in mainstream primary schools? Findings from a } \\
\text { systematic review of research }\end{array}$ & $\begin{array}{l}\text { Teacher competences and pupil achievement } \\
\text { in pre-school and school }\end{array}$ & $\begin{array}{l}\text { Effective early childhood education } \\
\text { programs: A systematic review }\end{array}$ \\
\hline $\begin{array}{l}\text { Organisation/Centre who } \\
\text { conducted the review }\end{array}$ & $\begin{array}{l}\text { School of Educational Foundations and Policy Studies, } \\
\text { Evidence for Policy and Practice Information and } \\
\text { Coordinating Centre (EPPI-centre), Social } \\
\text { Science Research Unit (SSRU) at the Institute of } \\
\text { Education, University of London }\end{array}$ & $\begin{array}{l}\text { Danish Clearinghouse } \\
\text { For Educational Research, School of } \\
\text { Education, University of Aarhus }\end{array}$ & $\begin{array}{l}\text { University of York and John Hopkins } \\
\text { University, The Centre for Reviews and } \\
\text { Dissemination (CRD) }\end{array}$ \\
\hline $\begin{array}{l}\text { Design of studies used in the } \\
\text { review }\end{array}$ & $\begin{array}{l}\text { Qualitatively and quantitatively designed studies } \\
\text { included }\end{array}$ & $\begin{array}{l}\text { Qualitatively and quantitatively designed } \\
\text { studies included }\end{array}$ & Quantitative measures were used \\
\hline Time period of studies included & 1975-1999 & $1998-2007$ & $1960-2010$ \\
\hline $\begin{array}{l}\text { Languages of publication of } \\
\text { studies used }\end{array}$ & Used mostly English publications & $\begin{array}{l}\text { English (64) } \\
\text { Spanish (1) } \\
\text { Portuguese (1) } \\
\text { German (1) } \\
\text { Chinese (1) } \\
\text { Danish (2) }\end{array}$ & English (40) \\
\hline Countries involved in studies & $\begin{array}{l}\text { United Kingdom (4), United States (18), } \\
\text { Other European countries, Australia, Canada (6) }\end{array}$ & $\begin{array}{l}\text { United States (34) } \\
\text { Great Britain (10) } \\
\text { Germany or German-speaking countries (4) } \\
\text { Nordic countries (5) } \\
\text { Other European countries (9) } \\
\text { Australia, New Zealand, Canada (7) } \\
\text { Other countries (7) }\end{array}$ & $\begin{array}{l}\text { All countries were included as long as the } \\
\text { studies were in English }\end{array}$ \\
\hline
\end{tabular}

Source: Authors' own work

TABLE 2: Quality assessment.

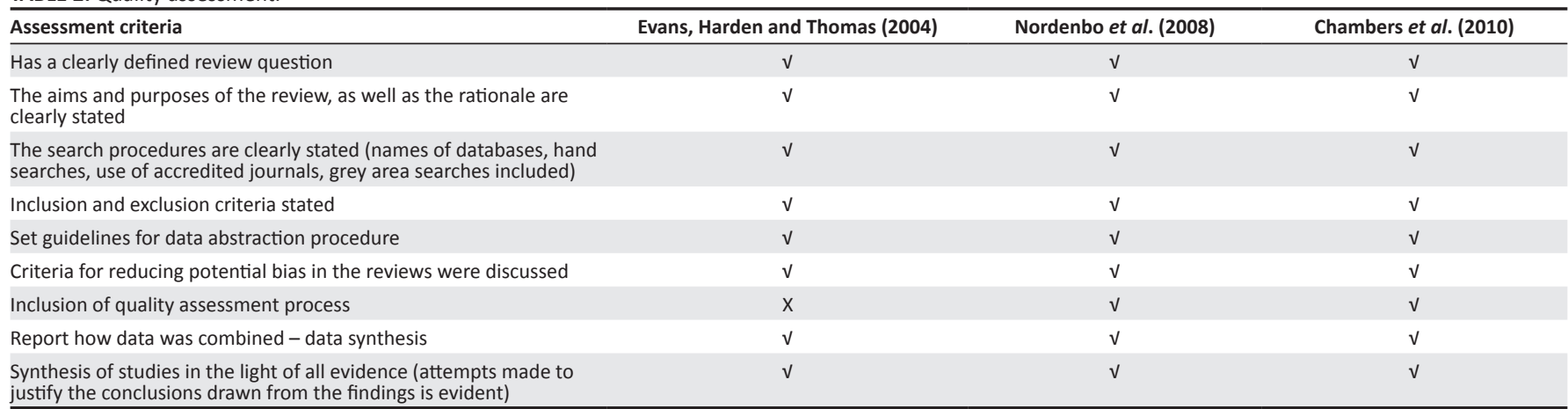

Source: Authors' own work 
Although this finding relates to special education needs of learners in mainstream schools, it is more likely than not that, when prospective foundation phase teachers enter the profession, they will be confronted with learners displaying disruptive behaviours and hence a component of their preservice programme should include training on dealing with learners and on systems of rewards for any form of progress they make towards shared goals.

Nordenbo et al. (2008) focus is on "which dimensions of teachers' manifest competencies' could contribute to pupil achievement. They concluded that 'three competences contribute to learning in children' (2008:73). These three competences are relational competencies (the teacher possesses the competence to enter into social relations with respect to the individual pupil), rule management competencies (the relation to the whole class, encouraging pupils to establish and maintain classroom rules - the teachers' role is that of a visible leader) and didactic competencies (in relation to the context of teaching, the teacher possesses the competence in the teaching and learning process in a general sense and in individual subjects taught). They suggest that the strong evidence emanating from the systematic review points in the direction:

that teacher training should focus on the development of these three basic competences and that all other details of teacher training should be able to be associated organically with one or more of these competences. (Nordenbo et al. 2008:74)

Chambers et al. (2010), who evaluated the effectiveness of early childhood education programmes, however, place emphasis on:

whether particular programmes produce positive outcomes and whether elements of these programmes contribute to effectiveness. (p. 2)

Their focus was on 'programs for young children who are at risk of school failure due to poverty' (2010:3) and on 'academic and cognitive outcomes' (2010:6). Six of the 28 early childhood development programmes showed strong evidence of effectiveness, especially relating to improved student outcomes. Of the six, three showed strong evidence at the end of kindergarten. These three are of particular interest for designing a foundation phase teacher education programme since they provide guidance on what can be included in such a programme in the South African context. The focus must be on Grade 1, where learners enter without a strong background of what is offered in a preschool setup. The characteristics of the three programmes which indicated strong evidence for effectiveness are a strong focus on language and literacy skills development, sequential thematic structuring of the programme, strong teacher-child relationships and encouragement of parental involvement in children's learning. The particular strong evidence of improved cognitive outcomes makes it imperative that pre-service teacher education programmes for foundation phase pay attention to skilling prospective teachers for the realisation of these features in practice.

\section{Conclusion}

A first issue which needs a response is the extent to which the review question has been answered. To recap the review question: What do quality research studies identify as the components/ characteristics of quality teacher education foundation phase programmes that allow new teachers to begin to teach for epistemological access? The paucity of research studies targeting entire programme effectiveness lead us to conclude that the question can only be partially answered. The partial answer pertains to some components of foundation phase programmes as is made clear below. With respect to teaching for epistemological access, there is less clarity, except perhaps the strong evidence of effectiveness, especially relating to improved student outcomes forthcoming from the systematic review of Chambers et al. (2010). For systematic reviews of educational research, it is conventional to provide recommendations for different role players affected by the educational enterprise. These are those involved in practice, policy and research. The domain of practice of this study is teacher education. With respect to practice, it comes through from this tertiary review that initial teacher education programmes should take cognisance of incorporating the following features:

- the notion of goal-sharing with young children and the value of systems of rewards for any form of progress they make towards these goals

- a strong focus on the development of relationship building, rule management and didactic competencies

- the prioritisation of language and literacy skills development

- structuring of learning programmes, both thematically and sequentially

- the skills to encourage parental involvement in children's learning, both in and out of school.

With regard to research, an issue coming through strongly from this study is that there is a dearth of research on entire programmes related to initial teacher education for foundation phase teachers. There are evaluation reports, such as the HEQC reports, on programmes in their entirety. These evaluations are executed by quality assurance agencies or they are commissioned by institutions for internal quality assurance purposes. Although they can be helpful, they are however not research reports in the strict sense of research as is evident from the limited specification of the underlying methods employed and a lack of in-depth literature reviews. They seldom focus entirely on the effectiveness of programmes. However, research does exist for components such as, for example, the teaching practicum and mentoring, content and approaches to subject matter comprising programmes, and so forth. It seems that the design of a programme will benefit more if systematic reviews of these components are undertaken. This will require large systematic review teams and the necessary resourcing of such teams. If one, for example, considers the components for the Bachelor of Education (B.Ed) (foundation phase) degree being designed, for which this tertiary review was conducted, then a minimum of five systematic review teams - one each for literacy, numeracy, practice teaching, life skills and educational studies - will be needed. We recommend that such a project be 
embarked upon. Recommendations for policy emanating from this study are that (1) there should be insistence from approval bodies for new programmes that submissions should indicate the research evidence which was taken into account for the design of programmes and (2) a similar insistence should be exercised for programme quality assurance. Such insistence will contribute towards the design of quality programmes and reviewing of existing programmes, since they will be driven by the best available research evidence.

\section{Acknowledgements Competing interests}

The authors declare that they have no financial or personal relationships which may have inappropriately influenced them in writing this article.

\section{Authors' contributions}

L.D. corresponding author and lead writer; M.Z. lead writer; C.J. lead writer; Z.D., B.D.W., L.H., N.M. and V.N. collaborators and reviewers.

\section{References}

Ashby, P., Hobson, A.J., Tracey, L., Malderez, A., Tomlinson, PD., Roper, T. et al., 2008 Beginner teachers' experiences of initial teacher preparation, induction and early professional development: A review of literature, Department for Children, Schools and Families, University of Nottingham.

Bowman, K.G., 2007, 'A research synthesis overview', Nursing Science Quarterly 20 171-176. http://dx.doi.org/10.1177/0894318407299575

Burkhardt, H. \& Schoenfeld, A.H., 2003, 'Improving educational research: Toward a more useful, more influential, and better-funded enterprise', Educational Researcher 32(9), 3-14. http://dx.doi.org/10.3102/0013189X032009003
Centre for Reviews and Dissemination (CRD), 2009, Systematic Reviews: CRD's guidance for undertaking reviews in health care, CRD, University of York, York.

Chambers, B., Cheung, A., Slavin, R., Smith, D. \& Laurenzano, M., 2010, Effective Early Childhood Education Programs: A systematic Review, viewed n.d., from files.eric ed.gov/fulltext/ED527643pdf

Cordingley, P., Bell, M., Rundell, B. \& Evans, D., 2003, 'The impact of collaborative CPD on classroom teaching and learning', in Research evidence in Education Library, Social Science Research Unit, Institute of Education, University of London, EPPIcentre, London, viewed n.d., from http://eppi.ioe.ac.uk/cms/Default.aspx?tabid= centre, London, view

Evans, J., Harden, A. \& Thomas, J., 2004, 'What are effective strategies to support pupils with emotional and behavioural difficulties (EBD) in mainstream primary schools? Findings from a systematic review of research', Journal of Research in Special EducationalNeeds 4(1),2-16. http://dx.doi.org/10.1111/J.1471-3802.2004.00015.x

Hobson, A.J., Malderez, A., Tracey, L, Giannakaki, M.S., Pell, G. \& Tomlinson, P.D. 2006, 'Student teachers' experiences of initial teacher preparation in England: Core themes and variation', paper presented at the European Conference on Educational Research (ECER), University of Geneva, Switzerland.

Jablonka, E., 2009, Unpublished seminar presented at University of Agder.

Lerman, S., Xu, G. \& Tsatsaroni, A., 2002, 'Developing theories of mathematics education research: The ESM Story', Educational Studies in Mathematics 51(1/2), 23-40. http://dx.doi.org/10.1023/A:1022412318413

Nordenbo, S.E., Søgaard Larsen, M., Tiftikiçi, N., Wendt, R.E. \& Østergaard, S., 2008, 'Teacher competences and pupil learning in pre-school and school-A systematic review carried out for the Ministry of Education and Research, Oslo', in Evidence base, pp. 1-96, Danish Clearinghouse for Educational Research, School of Education, University of Aarhus, Copenhagen.

Pawson, R., 2004, Mentoring relationships: An explanatory review, viewed 27 September 2012, from http://www.ccsr.ac.uk/methods/publications/

Pring, R., 2000, Philosophy of educational research, Continuum, London.

Rolnick, M., Adler, J. \& Setati, M. (eds.), 2009, African journal of research in mathematics, science and technology education, Special Edition November, pp. $115-130$.

Torgerson, C.J., 2007, 'The quality of systematic reviews of effectiveness in literacy learning in English: A "tertiary" review', Journal of Research in Reading 30(3), 287-315. http://dx.doi.org/10.1111/j.1467-9817.2006.00318.x

Vozzo, L., Abusson, P., Steele, F. \& Watson, K., 2004, 'Mentoring retrained teachers: Extending the web', Mentoring and Tutoring 12(3), 335-351. http://dx.doi. org/10.1080/030910042000275945

Yore, L.D. \& Lerman, S., 2008, 'Metasyntheses of qualitative research studies in Mathematics and Science Education', International Journal of Science and Mathematics Education 6, 217-223. http://dx.doi.org/10.1007/s10763-0089128-9 


\section{APPENDIX 1}

\section{Systematic Review Protocol - UWC EU/DHET Foundation Phase Research Group}

Name and affiliation of primary reviewer

Cyril Julie*

\section{Names and affiliations of co-reviewers}

Zubeida Desai, Vuyokazi Nomlomo, Nadeen Moolla, Lucinda du Plooy, Mphumzi Zilindile, Lorna Holtman Benita De Wet

*All reviewers and co-reviewers, except Ms De Wet who is a librarian at UWC, are members of the Faculty of Education, UWC

\section{Provisional title}

Programmes that prepare prospective foundation phase teachers for quality teaching.

\section{Objective}

The objective of the review is to systematically search for, identify, locate and narratively synthesise high-quality evidence that can inform us about the effectiveness of programme modalities for graduating beginner teachers for the foundation phase equipped to engage in quality teaching.

\section{Rationale for review / background}

This systematic review is part of a research and development project by a consortium consisting of the Walter Sisulu University (WSU), University of the Western Cape (UWC), Rhodes University (RU) and the Nelson Mandela Metropolitan University (NMMU). Broadly, the aims of the research and development project are research which will inform the delivery and the design of foundation phase teacher education programmes. This systematic review is concerned with the latter.

\section{Review question}

What do quality research studies identify as the components/ characteristics of quality teacher education foundation phase programmes that allow new teachers to begin to teach for epistemological access?

\section{Method}

The methods of the review are informed by both the metaanalysis of quantitative studies and meta-synthesis of qualitative studies. The types of studies included are those that adequately address the review objective. The focus will be on research results from quality studies. The sources to be used are academic journals, conference proceedings, evaluation reports and hard-to-locate 'grey' literature such as unpublished theses. The review will access studies over the range of subjects taught in the foundation phase and focus on both initial teacher education and continuous professional development programmes.

Given an initial assumption that there will be few studies dealing with the review objective, the period will be 1980 to 2010 .

Studies reporting results on both holistic programme design and subsets such as the results from research on specific components or subjects of foundation phase programme and their effects will be included.

Appraisal for inclusion of studies will be template driven with a negotiated agreed template developed by the systematic UWC review team and circulated to members of the consortium for possible revision and comprehensiveness. The proposed codes of the template for appraisal will be mined from existing systematic reviews and will be particularised for the review.

Relevant data from the included studies will initially be country, setting, aims and objectives, research design, participants, inclusion criteria, interventions and control or comparison conditions and results.

In order to ensure quality assurance, the procedures of independent double screening for data extraction, quality appraisal and extraction of outcomes will be undertaken.

Procedures to internally and externally assure the quality of each stage of the review will be set up.

Appropriate software will be used to organise and manage the titles, abstracts and bibliographic details of the sources retrieved through the searches.

Where deemed appropriate the Evidence for Policy and Practice Information (EPPI) of the Institute of Education, University of London will be approached for use of software for data extraction and coding tools for education studies. 


\section{APPENDIX 2}

\section{Foundation phase project systematic review}

Stage 0 Template

Publication

\begin{tabular}{|c|c|c|}
\hline Title & Author & $\begin{array}{c}\text { Systematic Review } \\
\text { (Yes / No) }\end{array}$ \\
\hline
\end{tabular}

Criteria for appraising systematic review articles in Stage 0

(Mark with ' $\mathrm{X}$ ')

\begin{tabular}{|c|c|c|c|c|c|c|}
\hline $\begin{array}{l}\text { Clearly defined } \\
\text { review question } \\
\text { (PICOS) }\end{array}$ & $\begin{array}{l}\text { Search strategy } \\
\text { (adequate and } \\
\text { appropriate?) }\end{array}$ & $\begin{array}{l}\text { Minimisation of bias } \\
\text { and errors in the } \\
\text { selection process }\end{array}$ & $\begin{array}{l}\text { Minimisation of bias and } \\
\text { errors in the quality } \\
\text { assessment process }\end{array}$ & $\begin{array}{l}\text { Minimisation of bias } \\
\text { and errors in the data } \\
\text { extraction process }\end{array}$ & $\begin{array}{l}\text { Presentation of } \\
\text { adequate details for } \\
\text { each primary study }\end{array}$ & $\begin{array}{cc}\text { Methods used for data } & \text { Evidence authors' } \\
\text { synthesis (assessed, } & \text { conclusions accurately } \\
\text { pooled and meaningful?) } & \begin{array}{c}\text { reflect the evidence } \\
\text { reviewed }\end{array}\end{array}$ \\
\hline
\end{tabular}

Decision: Reject

Accept for FPP

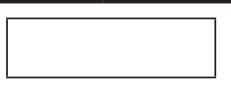

Accept for FPP

Criteria for judging publication: Relevance to the Foundation Phase Project (FPP)

\begin{tabular}{ccc}
\hline Bank & $\begin{array}{c}\text { Usefulness (citations for } \\
\text { further searches) }\end{array}$ & $\begin{array}{c}\text { Relevance in terms of } \\
\text { the FPP }\end{array}$ \\
\hline Procedure & Programme design & \\
\hline
\end{tabular}

General comments: 
APPENDIX 3

TABLE 1-A3: Nineteen reviewed articles.

\begin{tabular}{|c|c|c|c|c|c|}
\hline \multirow[t]{2}{*}{$\overline{\text { Author(s), date }}$} & \multirow[t]{2}{*}{ Title } & \multicolumn{2}{|c|}{ Systematic review } & \multirow{2}{*}{$\begin{array}{l}\text { Accept/Reject for } \\
\text { FFP }\end{array}$} & \multirow[t]{2}{*}{ Comment } \\
\hline & & Yes & No & & \\
\hline Leask (2004) & $\begin{array}{l}\text { Using research and evidence to improve teaching and } \\
\text { learning in the training of professionals - an example } \\
\text { from teacher training in England. }\end{array}$ & & 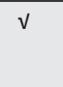 & Reject & \\
\hline Wong and Wong (2003) & $\begin{array}{l}\text { The evaluation of a teacher training programme in } \\
\text { school management: The case of Hong Kong. }\end{array}$ & & $\checkmark$ & Reject & \\
\hline $\begin{array}{l}\text { ETUCE - European Trade Union Committee } \\
\text { for Education (2008) }\end{array}$ & Teacher education in Europe: An ETUCE policy paper. & & $\checkmark$ & Accept & $\begin{array}{l}\text { The paper deals with } \\
\text { pre-service and in-service } \\
\text { teachers. It also focuses on } \\
\text { recruitment and retention } \\
\text { of teachers. }\end{array}$ \\
\hline Nordenbo et al. (2008) & $\begin{array}{l}\text { Teacher competences and pupil achievement in } \\
\text { pre-school and school. }\end{array}$ & $v$ & & Accept & \\
\hline Council on Higher Education (CHE) (2010) & $\begin{array}{l}\text { Report on the national review of academic and } \\
\text { professional programmes in education. }\end{array}$ & & $\checkmark$ & Accept & $\begin{array}{l}\text { The report is most relevant } \\
\text { in programme design } \\
\text { because of the } \\
\text { qualification structure for a } \\
\text { BEd programme being } \\
\text { discussed. }\end{array}$ \\
\hline Guskey (1995) & $\begin{array}{l}\text { International perspective teacher preparation - new } \\
\text { paradigm in teacher education, what do teachers need } \\
\text { to know? }\end{array}$ & & $\checkmark$ & Reject & \\
\hline Chambers et al. (2010) & $\begin{array}{l}\text { Effective early childhood education programs: A } \\
\text { systematic review. }\end{array}$ & $\checkmark$ & & Accept & \\
\hline Pontiveros (2001) & $\begin{array}{l}\text { Pre-service and in-service teacher education in the } \\
\text { Philippines. }\end{array}$ & & $\checkmark$ & Reject & \\
\hline Nkumbi, Warioba and Komba (2006) & $\begin{array}{l}\text { Capacity of primary school management for professional } \\
\text { development in selected primary schools in Tanzania. }\end{array}$ & & $\checkmark$ & Reject & \\
\hline Ashby et al. (2008) & $\begin{array}{l}\text { Beginner teachers' experiences of initial teacher } \\
\text { preparation, induction and early professional } \\
\text { development: A review of literature. }\end{array}$ & & $\checkmark$ & Reject & $\begin{array}{l}\text { The publication is an } \\
\text { extensive, in-depth } \\
\text { literature review. }\end{array}$ \\
\hline Adeosun (2010) & $\begin{array}{l}\text { Teacher education programmes and the acquisition of } \\
\text { 21st century skills: Issues and challenges in Nigeria. }\end{array}$ & & v & Accept & $\begin{array}{l}\text { Relevance for programme } \\
\text { design. }\end{array}$ \\
\hline Musset (2010) & $\begin{array}{l}\text { Initial teacher education and continuing training policies } \\
\text { in a comparative perspective: } \\
\text { Current practices in OECD countries and a literature } \\
\text { review on potential effects. }\end{array}$ & & $\checkmark$ & Accept & $\begin{array}{l}\text { This publication is more of } \\
\text { a literature review } \\
\text { although drawing on } \\
\text { results from research for } \\
\text { recommendations. }\end{array}$ \\
\hline Evans, Harden and Thomas (2004) & $\begin{array}{l}\text { What are effective strategies to support pupils with } \\
\text { emotional and behavioural difficulties (EBD) in } \\
\text { mainstream primary schools? Findings from a systematic } \\
\text { review of research. }\end{array}$ & v & & Accept & $\begin{array}{l}\text { This publication is useful to } \\
\text { assist in conducting a } \\
\text { proper systematic review; } \\
\text { it deals with primary } \\
\text { school children but only on } \\
\text { issues of behavioural } \\
\text { problems; the appendix } \\
\text { shows how the data could } \\
\text { be presented. }\end{array}$ \\
\hline Boaduo, Milondzo and Gumbi (2011) & $\begin{array}{l}\text { Teacher education and training for Africa in the 21st } \\
\text { century: What form should it take? }\end{array}$ & & $\checkmark$ & Accept & It is an opinion piece. \\
\hline Council on Higher Education (2010) & $\begin{array}{l}\text { Report on the National } \\
\text { Review of Academic and } \\
\text { Professional Programmes } \\
\text { in Education. }\end{array}$ & & $\checkmark$ & Accept & $\begin{array}{l}\text { This publication could } \\
\text { inform programme design } \\
\text { because it deals with } \\
\text { higher education } \\
\text { programmes in South } \\
\text { Africa. }\end{array}$ \\
\hline Thoman (1995) & $\begin{array}{l}\text { International perspective teacher preparation - new } \\
\text { paradigm in teacher education, what do teachers need } \\
\text { to know? }\end{array}$ & & $\checkmark$ & Accept & $\begin{array}{l}\text { Usefulness (citations for } \\
\text { further searches), } \\
\text { literature review, focuses } \\
\text { on teacher } \\
\text { professionalism. }\end{array}$ \\
\hline Nind (2006) & $\begin{array}{l}\text { Conducting systematic review in } \\
\text { education: a reflexive narrative. }\end{array}$ & & $v$ & Accept & $\begin{array}{l}\text { This publication offers a } \\
\text { reflexive narrative on the } \\
\text { process of conducting } \\
\text { systematic reviews. }\end{array}$ \\
\hline
\end{tabular}




\section{APPENDIX 4}

TABLE: 2-A4: FPP - Version 2 screening template.

\begin{tabular}{|c|c|c|c|}
\hline Criteria & Include (tick) & Exclude (tick) & Reason/comment \\
\hline Scope & $\checkmark$ & & Deals with methods used and findings of a Systematic Review \\
\hline School level & $v$ & & Relevant to foundation phase pre-school and school \\
\hline $\begin{array}{l}\text { Paper (empirical research, editorial, book review, policy doc, } \\
\text { resource guide, LTSM, opinion paper, theoretical paper, research } \\
\text { methodology paper, description/design of courses, etc.) }\end{array}$ & $v$ & & Systematic Review report \\
\hline Research focus (original data) & $\checkmark$ & & Relevant - Systematic Review: Methods and Findings \\
\hline Time period (post 1980) & $\checkmark$ & & Recent publication - 2008 \\
\hline $\begin{array}{l}\text { Bank?? } \\
\text { Accept }\end{array}$ & & & A good source to inform the Systematic Review of current project \\
\hline
\end{tabular}

Accept

Source: Nordenbo, S.E., Søgaard Larsen, M., Tiftikiçi, N., Wendt, R.E., \& Østergaard, S., 2008, Teacher competences and pupil learning in pre-school and school - A systematic review carried out for the Ministry of Education and Research, Oslo. In: Evidence base. Copenhagen: Danish Clearinghouse for Educational Research, School of Education, University of Aarhus 